in vivo $35: 2513-2519(2021)$

doi:10.21873/invivo.12532

Review

\title{
Effects of the Hypnotic Alkylphenol Derivative Propofol on Breast Cancer Progression. A Focus on Preclinical and Clinical Studies
}

\author{
SABRINA BIMONTE ${ }^{1 *}$, MARCO CASCELLA ${ }^{1 *}$, CIRA ANTONIETTA FORTE $^{1 *}$, GENNARO ESPOSITO $^{1}$, \\ FRANCESCO DEL PRATO ${ }^{1}$, NICOLA RAIANO ${ }^{2}$, PAOLA DEL PRETE ${ }^{3}$ and ARTURO CUOMO ${ }^{1}$ \\ ${ }^{1}$ Division of Anesthesia and Pain Medicine, Istituto Nazionale Tumori, \\ IRCCS Fondazione G. Pascale, Naples, Italy; \\ ${ }^{2}$ Radiology Division, Istituto Nazionale Tumori, \\ IRCCS Fondazione G. Pascale, Via Mariano Semmola, Naples, Italy; \\ ${ }^{3}$ Direzione Scientifica, Istituto Nazionale Tumori, IRCCS Fondazione G. Pascale, Naples, Italy
}

\begin{abstract}
Propofol is a hypnotic alkylphenol derivative with many biological activities. It is predominantly used in anesthesia and is the most used parenteral anesthetic agent in the United States. Accumulating preclinical studies have shown that this compound may inhibit cancer recurrence and metastasis. Nevertheless, other investigations provided evidence that this compound may promote breast cancer cell progression by modulating different molecular pathways. Clinical data on this topic are scarce and derive from retrospective analyses. For this reason, we reviewed and evaluated the available data to reveal insight into this controversial issue. More preclinical and clinical investigations are necessary to determine the potential role of propofol in the proliferation of breast cancer cells.
\end{abstract}

Breast cancer is the most widespread malignant tumor affecting women and represents the principal cause of their death worldwide (1). It is characterized by high invasiveness, and surgical resection represents the first line of treatment (2). Unfortunately, after surgery, patients with breast cancer

This article is freely accessible online.

*These Authors contributed equally to this study.

Correspondence to: Sabrina Bimonte, Division of Anesthesia and Pain Medicine, Istituto Nazionale Tumori, IRCCS Fondazione G. Pascale, Via Mariano Semmola 53, 80131 Naples, Italy. Tel: +39 0815903221, e-mail: s.bimonte@istitutotumori.na.it

Key Words: Propofol, breast cancer, cell proliferation, cancer migration, intravenous anesthetic, review. may develop local or distant metastases, which dramatically affects their survival rate (3).

In patients with cancer, the perioperative stress response may lead to the growth of cancer cells and to their dispersal in near or distant organs (4). In this scenario, pharmacological and non-pharmacological agents may play different roles in determining the stress response and, consequently, a potential deviation of the trajectory of the outcome. For instance, many pieces of evidence show that propofol, an alkylphenol derivative general anesthetic used for the induction and maintenance of anesthesia, may affect the long-term outcome of patients with breast cancer (5-7). Several in vitro studies performed on different cancer cell lines showed that due to its anti-inflammatory and antioxidative properties, propofol may restrain the expansion of cancer cells through the modulation of different signaling pathways (8). Conversely, because other preclinical studies showed that this compound may promote breast cancer cell progression, the matter remains not completely dissected.

This narrative review aimed to summarize these studies by discussing on the roles of propofol in breast cancer progression and recurrence.

Dissecting the Effects of Propofol on Tumor Cell Proliferation. Propofol (2, 6-diisopropylphenol) is largely used in general anesthesia, including in the setting of oncological surgery. Interestingly, recent studies featured the potential anticancer role of this compound in different types of tumors, including pancreatic, colonic, breast, hepatocellular, ovarian and prostate cancer (9-15). These investigations illustrate the molecular signaling pathways underlying the role of propofol in cancer development (16) (Table I). Specifically, as regards breast cancer, it has been 
in vivo $35: 2513-2519(2021)$

Table I. Molecular signaling pathways underlying the role of propofol in cancer development.

\begin{tabular}{|c|c|c|c|c|}
\hline Cancer type & Cell line & Treatment & Signaling pathways & Reference \\
\hline Ovarian & ES-2 & Propofol at 1,5 and $10 \mu \mathrm{g} / \mathrm{ml}$ Propofol for $24 \mathrm{~h}$ & NFkB $\downarrow$, miR-9 $\uparrow$ & 19 \\
\hline Pancreatic & MIAPaCa-2 & $\begin{array}{c}\text { 10-100 } \mu \mathrm{M} \text { Propofol or } 0.5 \mathrm{M} \mathrm{Na}_{2} \mathrm{CO}_{3} \text { (vehicle control) } \\
\text { for } 72 \mathrm{~h} 100 \mu \mathrm{mol} / 1 \text { per milliliter propofol for } 24,48,72 \mathrm{~h} \text {; } \\
\text { or } 10,25,50,100 \mu \mathrm{M} \text { gemcitabine for } 72 \mathrm{~h} \text {. } \\
\text { For combined treatment } 50 \text { or } 100 \mu \mathrm{mol} / 1 \\
\text { per milliliter propofol for } 24 \mathrm{~h} \text {, then } 10-100 \mu \mathrm{mol} / 1 \\
\text { gemcitabine for an additional } 72 \mathrm{~h}\end{array}$ & h; & 20 \\
\hline Cardia & Cancer cells & Propofol at $12.5,25$ and $50 \mu \mathrm{M}$ & MAPK/ERK $\downarrow$ & 21 \\
\hline $\begin{array}{l}\text { Mouse Leydig } \\
\text { tumor }\end{array}$ & MA 10 & Propofol at $300600 \mu \mathrm{M}$ for $24 \mathrm{~h}$ & MAPK $\uparrow$, AKT $\downarrow$ & 22 \\
\hline $\begin{array}{l}\text { Lung } \\
\text { adenocarcinoma }\end{array}$ & A549 & $\begin{array}{l}\text { Propofol at } 0,25,50 \text { and } 100 \mu \mathrm{g} / \mathrm{ml} \\
\text { for } 24 \text { and } 48 \mathrm{~h}\end{array}$ & $\begin{array}{c}\text { MMP2 } \downarrow, \text { MMP9 } \downarrow \\
\text { p38 } \downarrow, \text { MAPK } \downarrow\end{array}$ & 23 \\
\hline Colonic & LOVO & Propofol at 2,5 and $8 \mu \mathrm{g} / \mathrm{ml}$ for $24 \mathrm{~h}$ & ERK1/2 $\downarrow$, MMP2 $\downarrow$, MMP9 $\downarrow$ & 13 \\
\hline Pancreatic & MIAPaCa-2; Panc-1 & Propofol at 25,50 , and $100 \mu \mathrm{M}$ for $8 \mathrm{~h}$ & $\begin{array}{c}\text { CaMK II } \downarrow, \text { ERK } \downarrow, \text { AKT } \downarrow, \downarrow \\
\text { HIF } \alpha \downarrow \text {, VEGF } \downarrow \\
\text { NMDA receptor }\end{array}$ & 24 \\
\hline Pancreatic & Panc-1 & Propofol at $10 \mu \mathrm{g} / \mathrm{ml}$ for $0-72 \mathrm{~h}$ & ADAM8 $\downarrow$ & 25 \\
\hline Prostate & $\mathrm{LNCaP}$ & Propofol at 10 and $50 \mu \mathrm{M}$ for $8 \mathrm{~h}$ & HIF $1 \alpha \downarrow$, HIF $1 \beta \downarrow$ & 26 \\
\hline Prostate & PC3, DU145, and 22RV & $\begin{array}{l}\text { Docetaxel at } 0,6.25,12.5,25,50 \text { and } 100 \mu \mathrm{M} \\
\text { Propofol at } 0,1.25,2.5,5,10,20,40,80,160 \text {, and } 320 \mu \mathrm{M} \\
\text { Docetaxel alone or with docetaxel combined with propofol }\end{array}$ & HIF $1 \alpha \downarrow$ & 27 \\
\hline Ovarian & $\begin{array}{l}\text { HO-8910PM, H0-8910, } \\
\text { SKOV-3,OVCAR-3, } \\
\text { COC1 and ES-2 }\end{array}$ & $\begin{array}{c}\text { Paclitaxel at } 0.01-10 \mu \mathrm{M} 0.1-10 \mu \mathrm{g} / \mathrm{ml} \\
\text { of propofol for } 72 \mathrm{~h}\end{array}$ & SLUG $\downarrow$ & 29 \\
\hline Pancreatic & PANC-1 & $\begin{array}{l}\text { Propofol at } 1,5 \text { or } 10 \mu \mathrm{g} / \mathrm{ml} \text { for } 48 \mathrm{~h} \text {, } \\
\quad \text { or } 10 \mu \mathrm{g} / \mathrm{ml} \text { for } 12,24 \text { or } 36 \mathrm{~h}\end{array}$ & miR-21 $\downarrow$, SLUG $\downarrow$ & 30 \\
\hline Endometrial & Ishikawa & Propofol at 2,4 and $6 \mu \mathrm{g} / \mathrm{ml}$ for $24 \mathrm{~h}$ & WNT/ $\beta$-catenin $\downarrow$, SOX $4 \downarrow$ & 31 \\
\hline Breast & MDA-MB-468 & Propofol at $6 \mu \mathrm{g} / \mathrm{ml}$ for $7 \mathrm{~h}$ & GABA-A receptor $\uparrow$ & 32 \\
\hline Gallbladder & GBC-SD cells & Propofol at $0,10,20$ and $40 \mu \mathrm{M}$ for $72 \mathrm{~h}$ & NRF $2 \uparrow$ & 33 \\
\hline Breast & MDA-MB-231 & Propofol at 2,5 and $10 \mu \mathrm{g} / \mathrm{ml}$ for 1,4 and $12 \mathrm{~h}$ & NRF2 $\uparrow, \mathrm{p} 53 \downarrow$ & 34 \\
\hline Breast & MDA-MB-231 & Propofol at $0,2,5$ and $10 \mu \mathrm{g} / \mathrm{ml}$ for $24 \mathrm{~h}$ & MMP2 $\downarrow$, MMP9 $\downarrow$, NFKB $\downarrow$ & 35 \\
\hline
\end{tabular}

ADAM8: A disintegrin and metalloproteinase domain-containing protein 8, AKT: protein kinase B; CaMK II: calcium ion/calmodulin-dependent protein kinase class of enzymes; ERK: extracellular signal-regulated kinases; GABA-A: $\gamma$-aminobutyric acid type A ; HIF: hypoxia-inducible faxtor; MAPK: mitogen-activated protein kinase; miR: microRNA; MMP: metalloproteinase; NF-кB: nuclear factor-K-B; NMDA: N-methyl-D-aspartate receptor; NRF2: nuclear factor erythroid 2-related factor 2; SLUG: snail family transcriptional repressor 2; SOX9: SRY-Box Transcription Factor 9 ; VEGF: vascular endothelial growth factor. $\uparrow$ Up-regulated. $\downarrow$ Down-regulated.

demonstrated that propofol diminished the transient movement of MDA-MB-231 breast tumor cells by reducing the levels of matrix metalloproteinases (MMPs). This effect is mediated by the regulation of the nuclear factor $\mathrm{K} B$ (NF$\mathrm{kB})$ pathway (17). A comparative role was shown in MKN45 gastric cancer cells, in which their proliferation and invasion were restrained by the up-regulation of micro-RNA-195 (miR-195) and the inactivation of Janus kinase/signal transducer of activation pathways (18). Propofol also reduced ES-2 ovarian cancer cell movement through the upregulation of $m i R-9$ expression due to the activation of the NF-kB pathway (19). As regards pancreatic cancer, Du et al. found that by inactivating the $\mathrm{NF}-\mathrm{kB}$ signaling pathway, propofol instigated the chemosensitization of MIAPaCa-2 pancreatic cells to gemcitabine (20). Other evidence showed that propofol suppressed the multiplication of cardia tumor cells by repressing the mitogen-activated protein kinase (MAPK) and extracellular signal-regulated kinase (ERK) signaling pathways (21). Furthermore, it was shown that propofol provoked death of cardia cancer cells by activating the MAPK signaling pathway and by inhibiting the protein kinase B (AKT) pathway (22). In particular, propofol suppressed the migration of A549 lung cancer cells by downregulating the MMP2, MMP9, and p38 MAPK signaling pathways (23). Finally, propofol inhibited the invasion of LoVo human colorectal neoplastic cells through the downregulation of MMPs, which in turn, is strictly regulated by ERK1/2 signaling (13). Moreover, it has been demonstrated that the hypoxia pathway, which plays a significant role in cancer progression and the epithelial-to-mesenchymal transition (EMT), is linked to the effects of propofol on cancer development. Specifically, experimental studies 
conducted on pancreatic cancer cells (Miapaca-2 and Panc1 cells) indicated that propofol impaired the migration of these cells by regulating the expression of the $N$-methyl-Daspartate receptor (24). Moreover, Gao et al., showed that propofol, thought the involvement of the hypoxia pathway, reduced the expression of ADAM metallopeptidase domain containing metallopeptidase domain 8 in Panc-1 pancreatic cancer cells (25) and LNCaP prostate cancer cells (26). Finally, in prostate cancer cells, Quian et al. showed that propofol affected the EMT through the suppression of the hypoxia-inducible factor 1-alpha pathway (27).

SNAIL-related zinc-finger transcription factor SLUG (SNAI12) signaling is another propofol-regulated pathway that may favor its anticancer role (28). Specifically, it was shown that propofol stopped the invasion of different ovarian cancer cell lines (29) and PANC-1 pancreatic cancer cells (30) by improving apoptosis through the suppression of SLUG expression.

Overall, these findings indicate that propofol may suppress the development of different cancer cells by influencing diverse signaling pathways (31-34). Despite what might be expected, it was additionally indicated that propofol may promote the proliferation of diverse cancer cells, particularly breast cancer cells, primarily through the modulation of the NF-E2-related factor 2 (NRF2) pathway (17). These discrepancies may be associated with the experimental conditions such as i) different concentrations of propofol adopted; ii) different types of cancer cells; ii) different schedules of treatment.

The dual role of propofol on breast cancer development: a controversial issue. Distinctive pre-clinical studies have suggested that propofol has opposing effects on breast cancer development by involving diverse genetic signaling pathways (Table I). Discrepancies among studies are not only due to different experimental conditions but also to the heterogeneity of breast cancer itself $(35,36)$. It is important to underline that although breast cancer is normally identified as a single disease, it includes up to 21 diverse histological subtypes which respond distinctly to treatments and lead to multiple and diverse outcomes. This issue needs to be considered in terms of data interpretation.

Tumor growth-inhibitory effects. Several preclinical studies highlighted that propofol suppressed the proliferation and migration of breast cancer cells (Table II). Specifically, it was demonstrated that propofol repressed the migratory activity of breast cancer cells by down-regulating MMP2 and MMP9 expression, through the alteration of the NF-kB signaling pathway (17). Subsequently, a study conducted on MDA-MB-231 cells treated with two engineered conjugates of propofol, namely propofol-eicosapentaenoic and propofoldocosahexaenoic, highlighted for the first time the features of propofol-induced anticancer activity (37). Similarly to the previous report, it was later demonstrated that propofol attenuated the migration of MDA-MB-231 and MCF-7 cells, by managing the neuroepithelial-transforming 1 geneexpression profile (10). Similarly, a group of researchers provided evidence that by regulating the expression of $\mathrm{H} 19$, propofol diminished the proliferation of MDA-MB-231cells (38). Yu et al. subsequently showed that propofol increased the apoptosis of MDA-MB-435 cells by acting directly on miR-24/p27 molecular signaling (39). Du et al. discovered a regulatory association between propofol and EMT of MCF7 cells through the deregulation of $m i R-21$ which can interact with the phosphoinositide 3-kinase (PI3K)/AKT and WNT/ $\beta$-catenin pathways (40). Moreover, Li et al. conducted an in vivo study in two mouse models of breast cancer and demonstrated that mice receiving sevoflurane during surgical excision of primary tumor develop more lung metastases than those receiving propofol (41). Interestingly, different studies were conducted using MDA-MB-231 cells treated with serum from surgical breast cancer patients receiving different propofol/paravertebral block anesthesia or sevoflurane/opioid general anesthesia to elucidate the roles of propofol on breast cancer development (42-44). The data showed that the combination of regional anesthesia with propofol was more effective in the attenuation of breast cancer cell proliferation than the use of a volatile-opioid anesthetic regimen, thus reducing the risk of metastasis formation. Unfortunately, the underlying signaling pathway has not been completely elucidated, thus suggesting the need for additional studies.

Tumor growth-promoting effects. In two different studies, Garib et al. demonstrated that propofol enhanced the migration of MDA-MB-468 cells by regulating the activation of $\gamma$-aminobutyric acid type A $(32,45)$. Another study reported that propofol also increased the proliferation of MDA-MB-231 cells by reducing the expression of p53 through the regulation of the NRF2 signaling pathway (36).

Clinical research on the role of propofol in the outcome of patients with breast cancer. Uniquely in contrast to preclinical examinations, few clinical studies have been conducted on propofol breast development according to $\mathrm{Li}$ et al. (46). Moreover, these data come mainly from retrospective analyses. For instance, Enlud et al. carried out a retrospective study on the survival rate of patients subjected to mastectomy for breast cancer who were administered propofol versus those who underwent volatile anesthesia. In this setting, propofol enhanced survival rates or reduced cancer recurrence. Nevertheless, after correcting for confounders, these differences were not statistically significant (6). Moreover, Kim et al. showed that the effects of total intravenous anesthesia (TIVA) were comparable with 
Table II. The effects of propofol on breast cancer progression.

\begin{tabular}{|c|c|c|c|}
\hline $\begin{array}{l}\text { Breast cancer } \\
\text { cell line }\end{array}$ & Cell line & $\begin{array}{c}\text { Effect on breast cancer } \\
\text { development, signaling pathways }\end{array}$ & Reference \\
\hline MDA-MB-231 & Propofol at $0,2,5$ and $10 \mu \mathrm{g} / \mathrm{ml}$ for $24 \mathrm{~h}$ & $\begin{array}{l}\text { Impairment of migration and invasiveness } \\
\text { MMP } 2 \downarrow, \text { MMP9 } \downarrow, N F-\varkappa B \downarrow\end{array}$ & 17 \\
\hline MDA-MB-231 & $\begin{array}{l}\text { Propofol at } 3 \text { to } 8 \mu \mathrm{g} / \mathrm{ml} 20 \text { to } 50 \mu \mathrm{M} \text { for } 24 \mathrm{~h} \\
\text { Propofol-DHA or propofol-EPA at } 25 \mu \mathrm{M} \text { for } 24 \mathrm{~h}\end{array}$ & $\begin{array}{l}\text { Inhibition of cell migration and adhesion, } \\
\text { and enhancement of apoptosis }\end{array}$ & 37 \\
\hline $\begin{array}{l}\text { MDA-MB-231, } \\
\text { MCF-7 }\end{array}$ & $\begin{array}{l}\text { Propofol at } 1-10 \mu \mathrm{g} / \mathrm{ml} \\
\text { Bupivacaine at } 0.5-100 \mu \mathrm{g} / \mathrm{ml} \text { for } 6-24 \mathrm{~h} \text {. }\end{array}$ & $\begin{array}{c}\text { Inhibition of migration } \\
\text { NET1 } \downarrow\end{array}$ & 10 \\
\hline MDA-MB-231 & Propofol at 25,50 , and $100 \mu \mathrm{M}$ for $24 \mathrm{~h}$ & $\begin{array}{c}\text { Inhibition of migration and the invasion } \\
\text { of breast cancer cell H19 }\end{array}$ & 38 \\
\hline MDA-MB-435 & Propofol at $10 \mu \mathrm{M}$ for $6 \mathrm{~h}$ & $\begin{array}{l}\text { Enhancement of the apoptosis of breast cancer cells. } \\
\text { Cleaved caspase- } 3 \uparrow, p 27 \uparrow, \text { miR- } 24 \downarrow\end{array}$ & 39 \\
\hline MCF-7 & Propofol at $0-10 \mu \mathrm{g} / \mathrm{ml}$ for $48 \mathrm{~h}$ & $\begin{array}{l}\text { Inhibition of the proliferation, EMT and enhancement } \\
\text { of apoptosis of breast cancer cells. } \\
\text { miR-21 } \uparrow, \text { p53 } \uparrow, \text { WNT/ } \beta \text {-catenin } \downarrow, \text { PI3K/AKT } \downarrow\end{array}$ & 40 \\
\hline MDA-MB-468 & $\begin{array}{l}\text { Propofol at } 3,6,9 \mathrm{mg} / 1 \text {, etomidate at } 2,3,4 \mu \mathrm{g} / \mathrm{ml} \text {, } \\
\text { and lidocaine at } 1.25,2.5,5 \mu \mathrm{g} / \mathrm{ml} \text { up to } 10 \mathrm{~h}\end{array}$ & Enhancement of migratory activity of tumor cells & 41 \\
\hline MDA-MB-468 & Propofol at $6 \mu \mathrm{g} / \mathrm{ml}$ for $3 \mathrm{~h}$ & $\begin{array}{c}\text { Enhancement of migration of tumor cells. } \\
\text { Activation of GABA-A receptor. } \\
\text { Reorganization of the actin cytoskeleton. }\left[\mathrm{Ca}^{2+}\right] \uparrow\end{array}$ & 32 \\
\hline MDA-MB-231 & Propofol at 2,5 and $10 \mu \mathrm{g} / \mathrm{ml}$ for 1,4 and $12 \mathrm{~h}$ & $\begin{array}{l}\text { Increased proliferation, which was at least partially } \\
\text { associated with inhibition of expression of p53. } \\
\text { Induced cell migration, which was involved } \\
\text { in activation of the NRF2 pathway }\end{array}$ & 34 \\
\hline
\end{tabular}

DHA: Docosahexaenoic acid; EMT: epithelial-mesenchymal transition; EPA: eicosapentaenoic acid; GABA-A: $\gamma$-aminobutyric acid type A; H19: imprinted maternally expressed transcript; miR: microRNA; MMP: metalloproteinase; NET1: neuroepithelial cell-transforming 1; NF- $\varkappa$ B: nuclear factor kappa B; NRF2: nuclear factor erythroid 2-related factor 2; PI3K/AKT: phosphoinositide 3-kinase/protein kinase B. $\uparrow$ Up-regulated. $\downarrow$ Downregulated.

those of volatile anesthesia in terms of cancer recurrence and overall survival (47). On the other hand, in another retrospective analysis, Lee et al. found that propofol-based TIVA reduced the risk of breast cancer recurrence 5 years after surgery (7). Wingmore et al. also found significantly better long-term survival rates for patients receiving propofol [3, 714 patients, 504 deaths $(13.5 \%)]$ compared to patients receiving volatile anesthetics [3, 316 patients, 796 deaths (24\%)] following cancer surgery (48). Recently, different results were obtained in a retrospective study in which propofol TIVA was compared with volatile anesthetics in patients subjected to breast cancer surgery. The authors showed that neither propofol nor desflurane affected patient prognosis and survival (49). Similar negative findings were described by Sessler et al. in a recent randomized controlled clinical trial. They demonstrated that regional anesthesiaanalgesia (paravertebral block and propofol) did not lower breast cancer recurrence after surgery compared with opioids and volatile anesthesia (sevoflurane) (50).

Altogether, these contrasting results suggest a need for prospective studies to elucidate this controversial issue. The principal aim of such clinical studies is to find a convincing relationship between propofol and breast cancer outcomes. To date, four prospective studies which compared propofol with sevoflurane in patients with breast cancer are available (51-54). Altogether, these studies highlighted the effects of propofol on outcomes of patients subjected to breast cancer surgery. Importantly propofol has also been shown to reduce the development and severity of acute and chronic pain following surgery (55).

Using systems biology, the mechanism of propofol-induced effects on breast cancer cells should be explored through various 'omics' technologies, as reported by Wang et al. (56) On the other hand, cancer cell lines can only reflect part of the overall impact of propofol on cancer, as propofol may affect the progression of cancer in many other aspects.

\section{Conclusion}

In this narrative review, we dissected the effects of propofol on the development of breast tumors. Propofol may exert its pro- or antitumor activity on breast cancer by regulating different molecular mechanisms that have not been fully elucidated. Moreover, the high heterogeneity of breast cancer may obscure a consistent mechanism of action for propofol. Unexpectedly, in clinical settings, a few reports demonstrated that propofol may advance breast cancer development. Because available clinical data are scarce, these findings 
require further confirmation. Thus, more pre-clinical and clinical investigations are necessary to translate the preclinical studies into clinical practice, potentially in order to develop new propofol-based therapies that will improve the outcomes of a patient subjected to breast oncological surgery.

\section{Conflicts of Interest}

The Authors declare no conflicts of interest.

\section{Authors' Contributions}

The present article was mainly written by SB, AC and MC. All Authors contributed toward data analysis, drafting and critically revised the paper, gave final approval of the version to be published, and agreed to be accountable for all aspects of the work.

\section{Acknowledgements}

The Authors are grateful to Dr. Alessandra Trocino and Mrs. Cristina Romano from the National Cancer Institute of Naples for providing excellent bibliographic service and assistance.

\section{References}

1 American Cancer Society. Cancer Facts \& Figures Atlanta: American Cancer Society 2017. Available at: https:// www.cancer.org/content/dam/cancer-org/research/cancer-factsand-statistics/annual-cancer-facts-and-figures/2017/cancer-factsand-figures-2017.pdf [Last accessed on May 31 st, 2021]

2 DeSantis CE, Lin CC, Mariotto AB, Siegel RL, Stein KD, Kramer JL, Alteri R, Robbins AS and Jemal A: Cancer treatment and survivorship statistics, 2014. CA Cancer J Clin 64(4): 252271, 2014. PMID: 24890451. DOI: 10.3322/caac.21235

3 Rafferty EA, Park JM, Philpotts LE, Poplack SP, Sumkin JH, Halpern EF and Niklason LT: Assessing radiologist performance using combined digital mammography and breast tomosynthesis compared with digital mammography alone: results of a multicenter, multireader trial. Radiology 266(1): 104-113, 2013 PMID: 23169790. DOI: 10.1148/radiol.12120674

4 Al-Sahaf O, Wang JH, Browne TJ, Cotter TG and Redmond HP: Surgical injury enhances the expression of genes that mediate breast cancer metastasis to the lung. Ann Surg 252(6): 1037-1043, 2010. PMID: 21107114. DOI: 10.1097/SLA.0b013e3181efc635

5 Wigmore TJ, Mohammed K and Jhanji S: Long-term survival for patients undergoing volatile versus IV anesthesia for cancer surgery: A retrospective analysis. Anesthesiology 124(1): 69-79, 2016. PMID: 26556730. DOI: 10.1097/ALN.0000000000000936

6 Enlund M, Berglund A, Andreasson K, Cicek C, Enlund A and Bergkvist L: The choice of anaesthetic-sevoflurane or propofol-and outcome from cancer surgery: a retrospective analysis. Ups J Med Sci 119(3): 251-261, 2014. PMID: 24857018. DOI: $10.3109 / 03009734.2014 .922649$

7 Lee JH, Kang SH, Kim Y, Kim HA and Kim BS: Effects of propofol-based total intravenous anesthesia on recurrence and overall survival in patients after modified radical mastectomy: a retrospective study. Korean J Anesthesiol 69(2): 126-132, 2016. PMID: 27066202. DOI: 10.4097/kjae.2016.69.2.126
8 Bimonte S, Cascella M, Giudice A, Bifulco F, Wirz S and Cuomo A: Propofol Effects in Breast Cancer Cell Progression: Evidences from In Vitro Studies. General Anesthesia Research: 147-157, 2021. DOI: 10.1007/978-1-4939-9891-3_9

$9 \mathrm{Ou} \mathrm{W,} \mathrm{Lv} \mathrm{J,} \mathrm{Zou} \mathrm{X,} \mathrm{Yao} \mathrm{Y,} \mathrm{Wu} \mathrm{J,} \mathrm{Yang} \mathrm{J,} \mathrm{Wang} \mathrm{Z} \mathrm{and} \mathrm{Ma} \mathrm{Y:}$ Propofol inhibits hepatocellular carcinoma growth and invasion through the HMGA2-mediated Wnt/ $\beta$-catenin pathway. Exp Ther Med 13(5): 2501-2506, 2017. PMID: 28565871. DOI: 10.3892/etm.2017.4253

10 Ecimovic P, Murray D, Doran P and Buggy DJ: Propofol and bupivacaine in breast cancer cell function in vitro - role of the NET1 gene. Anticancer Res 34(3): 1321-1331, 2014. PMID: 24596379.

11 Cui WY, Liu Y, Zhu YQ, Song T and Wang QS: Propofol induces endoplasmic reticulum (ER) stress and apoptosis in lung cancer cell H460. Tumour Biol 35(6): 5213-5217, 2014. PMID: 24510348. DOI: $10.1007 / \mathrm{s} 13277-014-1677-7$

12 Wang ZT, Gong HY, Zheng F, Liu DJ and Dong TL: Propofol suppresses proliferation and invasion of pancreatic cancer cells by upregulating microRNA-133a expression. Genet Mol Res 14(3): 7529-7537, 2015. PMID: 26214431. DOI: 10.4238/ 2015.July.3.28

13 Miao Y, Zhang Y, Wan H, Chen L and Wang F: GABA-receptor agonist, propofol inhibits invasion of colon carcinoma cells. Biomed Pharmacother 64(9): 583-588, 2010. PMID: 20888181. DOI: 10.1016/j.biopha.2010.03.006

14 Zhang YF, Li CS, Zhou Y and Lu XH: Effects of propofol on colon cancer metastasis through STAT3/HOTAIR axis by activating WIF-1 and suppressing Wnt pathway. Cancer Med 9(5): 1842-1854, 2020. PMID: 31953926. DOI: 10.1002/ cam4.2840

15 Sun Y, Peng YB, Ye LL, Ma LX, Zou MY and Cheng ZG: Propofol inhibits proliferation and cisplatin resistance in ovarian cancer cells through regulating the microRNA-374a/forkhead box O1 signaling axis. Mol Med Rep 21(3): 1471-1480, 2020. PMID: 32016462. DOI: 10.3892/mmr.2020.10943

16 Gao X, Mi Y, Guo N, Luan J, Xu H, Hu Z, Wang N, Zhang D, Gou $\mathrm{X}$ and $\mathrm{Xu} \mathrm{L}$ : The mechanism of propofol in cancer development: An updated review. Asia Pac J Clin Oncol 16(2): e3-e11, 2020. PMID: 31970936. DOI: 10.1111/ajco.13301

17 Li Q, Zhang L, Han Y, Jiang Z and Wang Q: Propofol reduces MMPs expression by inhibiting NF-kB activity in human MDAMB-231 cells. Biomed Pharmacother 66(1): 52-56, 2012. PMID: 22264881. DOI: 10.1016/j.biopha.2011.10.006

18 Zhang W, Wang Y, Zhu Z, Zheng Y and Song B: Propofol inhibits proliferation, migration and invasion of gastric cancer cells by up-regulating microRNA-195. Int J Biol Macromol 120(Pt A): 975-984, 2018. PMID: 30171944. DOI: 10.1016/ j.ijbiomac.2018.08.173

19 Huang X, Teng Y, Yang H and Ma J: Propofol inhibits invasion and growth of ovarian cancer cells via regulating miR-9/NF-kB signal. Braz J Med Biol Res 49(12): e5717, 2016. PMID: 27982283. DOI: 10.1590/1414-431X20165717

20 Du QH, Xu YB, Zhang MY, Yun P and He CY: Propofol induces apoptosis and increases gemcitabine sensitivity in pancreatic cancer cells in vitro by inhibition of nuclear factor-kB activity. World J Gastroenterol 19(33): 5485-5492, 2013. PMID: 24023491. DOI: $10.3748 /$ wjg.v19.i33.5485

$21 \mathrm{Su} \mathrm{Z}$, Liu HL, Qi B and Liu Y: Effects of propofol on proliferation and apoptosis of cardia cancer cells via 
MAPK/ERK signaling pathway. Eur Rev Med Pharmacol Sci 24(1): 428-433, 2020. PMID: 31957857. DOI: 10.26355/ eurrev_202001_19942

22 Kang FC, Wang SC, So EC, Chang MM, Wong KL, Cheng KS, Chen YC and Huang BM: Propofol may increase caspase and MAPK pathways, and suppress the Akt pathway to induce apoptosis in MA-10 mouse Leydig tumor cells. Oncol Rep 41(6): 3565-3574, 2019. PMID: 31002349. DOI: 10.3892/or.2019.7129

$23 \mathrm{Wu}$ KC, Yang ST, Hsia TC, Yang JS, Chiou SM, Lu CC, Wu RS and Chung JG: Suppression of cell invasion and migration by propofol are involved in down-regulating matrix metalloproteinase-2 and p38 MAPK signaling in A549 human lung adenocarcinoma epithelial cells. Anticancer Res 32(11): 4833-4842, 2012. PMID: 23155249.

24 Chen X, Wu Q, You L, Chen S, Zhu M and Miao C: Propofol attenuates pancreatic cancer malignant potential via inhibition of NMDA receptor. Eur J Pharmacol 795: 150-159, 2017. PMID: 27986626. DOI: 10.1016/j.ejphar.2016.12.017

25 Gao Y, Yu X, Zhang F and Dai J: Propofol inhibits pancreatic cancer progress under hypoxia via ADAM8. J Hepatobiliary Pancreat Sci 26(6): 219-226, 2019. PMID: 30945470. DOI: $10.1002 /$ jhbp. 624

26 Tatsumi K, Hirotsu A, Daijo H, Matsuyama T, Terada N and Tanaka T: Effect of propofol on androgen receptor activity in prostate cancer cells. Eur J Pharmacol 809: 242-252, 2017. PMID: 28552345. DOI: 10.1016/j.ejphar.2017.05.046

27 Qian J, Shen S, Chen W and Chen N: Propofol reversed hypoxia-induced docetaxel resistance in prostate cancer cells by preventing epithelial-mesenchymal transition by inhibiting hypoxia-inducible factor $1 \alpha$. Biomed Res Int 2018: 4174232, 2018. PMID: 29568752. DOI: $10.1155 / 2018 / 4174232$

28 Phillips S and Kuperwasser C: SLUG: Critical regulator of epithelial cell identity in breast development and cancer. Cell Adh Migr 8(6): 578-587, 2014. PMID: 25482617. DOI: 10.4161/19336918.2014.972740

29 Wang P, Chen J, Mu LH, Du QH, Niu XH and Zhang MY: Propofol inhibits invasion and enhances paclitaxel- induced apoptosis in ovarian cancer cells through the suppression of the transcription factor slug. Eur Rev Med Pharmacol Sci 17(13): 1722-1729, 2013. PMID: 23852894.

30 Liu Z, Zhang J, Hong G, Quan J, Zhang L and Yu M: Propofol inhibits growth and invasion of pancreatic cancer cells through regulation of the miR-21/Slug signaling pathway. Am J Transl Res 8(10): 4120-4133, 2016. PMID: 27829997.

31 Du Q, Liu J, Zhang X, Zhang X, Zhu H, Wei M and Wang S: Propofol inhibits proliferation, migration, and invasion but promotes apoptosis by regulation of Sox 4 in endometrial cancer cells. Braz J Med Biol Res 51(4): e6803, 2018. PMID: 29490000. DOI: 10.1590/1414-431x20176803

32 Garib V, Lang K, Niggemann B, Zänker KS, Brandt L and Dittmar T: Propofol-induced calcium signalling and actin reorganization within breast carcinoma cells. Eur J Anaesthesiol 22(8): 609-615, 2005. PMID: 16119598. DOI: 10.1017/ s026502150500102x

33 Zhang L, Wang N, Zhou S, Ye W, Jing G and Zhang M: Propofol induces proliferation and invasion of gallbladder cancer cells through activation of Nrf2. J Exp Clin Cancer Res 31: 66, 2012. PMID: 22901367. DOI: 10.1186/1756-9966-31-66

34 Meng C, Song L, Wang J, Li D, Liu Y and Cui X: Propofol induces proliferation partially via downregulation of $\mathrm{p} 53$ protein and promotes migration via activation of the Nrf2 pathway in human breast cancer cell line MDA-MB-231. Oncol Rep 37(2): 841-848, 2017. PMID: 28035403. DOI: 10.3892/or.2016.5332

35 Yang XR, Chang-Claude J, Goode EL, Couch FJ, Nevanlinna H, Milne RL, Gaudet M, Schmidt MK, Broeks A, Cox A, Fasching PA, Hein R, Spurdle AB, Blows F, Driver K, Flesch-Janys D, Heinz J, Sinn P, Vrieling A, Heikkinen T, Aittomäki K, Heikkilä P, Blomqvist C, Lissowska J, Peplonska B, Chanock S, Figueroa J, Brinton L, Hall P, Czene K, Humphreys K, Darabi H, Liu J, Van 't Veer LJ, van Leeuwen FE, Andrulis IL, Glendon G, Knight JA, Mulligan AM, O'Malley FP, Weerasooriya N, John EM, Beckmann MW, Hartmann A, Weihbrecht SB, Wachter DL, Jud SM, Loehberg CR, Baglietto L, English DR, Giles GG, McLean CA, Severi G, Lambrechts D, Vandorpe T, Weltens C, Paridaens R, Smeets A, Neven P, Wildiers H, Wang X, Olson JE, Cafourek V, Fredericksen Z, Kosel M, Vachon C, Cramp HE, Connley D, Cross SS, Balasubramanian SP, Reed MW, Dörk T, Bremer M, Meyer A, Karstens JH, Ay A, Park-Simon TW, Hillemanns P, Arias Pérez JI, Menéndez Rodríguez P, Zamora P, Benítez J, Ko YD, Fischer HP, Hamann U, Pesch B, Brüning T, Justenhoven C, Brauch H, Eccles DM, Tapper WJ, Gerty SM, Sawyer EJ, Tomlinson IP, Jones A, Kerin M, Miller N, McInerney N, AntonCulver H, Ziogas A, Shen CY, Hsiung CN, Wu PE, Yang SL, Yu JC, Chen ST, Hsu GC, Haiman CA, Henderson BE, Le Marchand L, Kolonel LN, Lindblom A, Margolin S, Jakubowska A, Lubiński J, Huzarski T, Byrski T, Górski B, Gronwald J, Hooning MJ, Hollestelle A, van den Ouweland AM, Jager A, Kriege M, Tilanus-Linthorst MM, Collée M, Wang-Gohrke S, Pylkäs K, Jukkola-Vuorinen A, Mononen K, Grip M, Hirvikoski P, Winqvist R, Mannermaa A, Kosma VM, Kauppinen J, Kataja V, Auvinen P, Soini Y, Sironen R, Bojesen SE, Ørsted DD, KaurKnudsen D, Flyger H, Nordestgaard BG, Holland H, ChenevixTrench G, Manoukian S, Barile M, Radice P, Hankinson SE, Hunter DJ, Tamimi R, Sangrajrang S, Brennan P, McKay J, Odefrey F, Gaborieau V, Devilee P, Huijts PE, Tollenaar RA, Seynaeve C, Dite GS, Apicella C, Hopper JL, Hammet F, Tsimiklis H, Smith LD, Southey MC, Humphreys MK, Easton D, Pharoah P, Sherman ME and Garcia-Closas M: Associations of breast cancer risk factors with tumor subtypes: a pooled analysis from the Breast Cancer Association Consortium studies. J Natl Cancer Inst 103(3): 250-263, 2011. PMID: 21191117. DOI: 10.1093/jnci/djq526

36 Dieci MV, Orvieto E, Dominici M, Conte P and Guarneri V: Rare breast cancer subtypes: histological, molecular, and clinical peculiarities. Oncologist 19(8): 805-813, 2014. PMID: 24969162. DOI: 10.1634/theoncologist.2014-0108

37 Siddiqui RA, Zerouga M, Wu M, Castillo A, Harvey K, Zaloga GP and Stillwell W: Anticancer properties of propofoldocosahexaenoate and propofol-eicosapentaenoate on breast cancer cells. Breast Cancer Res 7(5): R645-R654, 2005. PMID: 16168109. DOI: $10.1186 /$ bcr1036

38 Bai JJ, Lin CS, Ye HJ, Guo PP and Wang W: [Propofol suppresses migration and invasion of breast cancer MDA-MB231 cells by down-regulating H19]. Nan Fang Yi Ke Da Xue Xue Bao 36(9): 1255-1259, 2016. PMID: 27687660.

39 Yu B, Gao W, Zhou H, Miao X, Chang Y, Wang L, Xu M and $\mathrm{Ni}$ G: Propofol induces apoptosis of breast cancer cells by downregulation of miR-24 signal pathway. Cancer Biomark 21(3): 513-519, 2018. PMID: 29103019. DOI: 10.3233/CBM170234 
40 Du Q, Zhang X, Zhang X, Wei M, Xu H and Wang S: Propofol inhibits proliferation and epithelial-mesenchymal transition of MCF-7 cells by suppressing miR-21 expression. Artif Cells Nanomed Biotechnol 47(1): 1265-1271, 2019. PMID: 30942630. DOI: $10.1080 / 21691401.2019 .1594000$

$41 \mathrm{Li}$ R, Huang Y and Lin J: Distinct effects of general anesthetics on lung metastasis mediated by IL-6/JAK/STAT3 pathway in mouse models. Nat Commun 11(1): 642, 2020. PMID: 32005799. DOI: 10.1038/s41467-019-14065-6

42 Deegan CA, Murray D, Doran P, Ecimovic P, Moriarty DC and Buggy DJ: Effect of anaesthetic technique on oestrogen receptornegative breast cancer cell function in vitro. Br J Anaesth 103(5): 685-690, 2009. PMID: 19776028. DOI: 10.1093/ bja/aep261

43 Jaura AI, Flood G, Gallagher HC and Buggy DJ: Differential effects of serum from patients administered distinct anaesthetic techniques on apoptosis in breast cancer cells in vitro: a pilot study. Br J Anaesth 113(Suppl 1): i63-i67, 2014. PMID: 25009197. DOI: 10.1093/bja/aet581

44 Buckley A, McQuaid S, Johnson P and Buggy DJ: Effect of anaesthetic technique on the natural killer cell anti-tumour activity of serum from women undergoing breast cancer surgery: a pilot study. Br J Anaesth 113(Suppl 1): i56-i62, 2014. PMID: 25009196. DOI: 10.1093/bja/aeu200

45 Garib V, Niggemann B, Zänker KS, Brandt L and Kubens BS: Influence of non-volatile anesthetics on the migration behavior of the human breast cancer cell line MDA-MB-468. Acta Anaesthesiol Scand 46(7): 836-844, 2002. PMID: 12139540. DOI: $10.1034 / \mathrm{j} .1399-6576.2002 .460714 . x$

46 Li R, Liu H, Dilger JP and Lin J: Effect of Propofol on breast Cancer cell, the immune system, and patient outcome. BMC Anesthesiol 18(1): 77, 2018. PMID: 29945542. DOI: 10.1186/ s12871-018-0543-3

47 Kim MH, Kim DW, Kim JH, Lee KY, Park S and Yoo YC: Does the type of anesthesia really affect the recurrence-free survival after breast cancer surgery? Oncotarget 8(52): 90477-90487, 2017. PMID: 29163846. DOI: 10.18632/oncotarget.21014

48 Wigmore TJ, Mohammed K and Jhanji S: Long-term survival for patients undergoing volatile versus IV anesthesia for cancer surgery: A retrospective analysis. Anesthesiology 124(1): 69-79, 2016. PMID: 26556730. DOI: 10.1097/ALN.0000000000000936

49 Huang YH, Lee MS, Lou YS, Lai HC, Yu JC, Lu CH, Wong CS and Wu ZF: Propofol-based total intravenous anesthesia did not improve survival compared to desflurane anesthesia in breast cancer surgery. PLoS One 14(11): e0224728, 2019. PMID: 31697743. DOI: 10.1371/journal.pone.0224728
50 Sessler DI, Pei L, Huang Y, Fleischmann E, Marhofer P, Kurz A, Mayers DB, Meyer-Treschan TA, Grady M, Tan EY, Ayad S, Mascha EJ, Buggy DJ and Breast Cancer Recurrence Collaboration: Recurrence of breast cancer after regional or general anaesthesia: a randomised controlled trial. Lancet 394(10211): 1807-1815, 2019. PMID: 31645288. DOI: 10.1016/ S0140-6736(19)32313-X

51 Subramani S and Poopalalingam R: Bonfils assisted double lumen endobronchial tube placement in an anticipated difficult airway. J Anaesthesiol Clin Pharmacol 30(4): 568-570, 2014. PMID: 25425788. DOI: 10.4103/0970-9185.142867

52 Weng H, Xu ZY, Liu J, Ma D and Liu DS: Placement of the Univent tube without fiberoptic bronchoscope assistance. Anesth Analg 110(2): 508-514, 2010. PMID: 19933530. DOI: 10.1213/ ANE.0b013e3181c5ed18

53 Schuepbach R, Grande B, Camen G, Schmidt AR, Fischer H, Sessler DI, Seifert B, Spahn DR and Ruetzler K: Intubation with VivaSight or conventional left-sided double-lumen tubes: a randomized trial. Can J Anaesth 62(7): 762-769, 2015. PMID: 25663254. DOI: $10.1007 / \mathrm{s} 12630-015-0329-8$

54 Desmond F, McCormack J, Mulligan N, Stokes M and Buggy DJ: Effect of anaesthetic technique on immune cell infiltration in breast cancer: a follow-up pilot analysis of a prospective, randomised, investigator-masked study. Anticancer Res 35(3): 1311-1319, 2015. PMID: 25750280.

$55 \mathrm{Ng}$ QX, Loke W, Yeo WS, Chng KYY and Tan CH: A metaanalysis of the utility of preoperative intravenous paracetamol for post-caesarean analgesia. Medicina (Kaunas) 55(8): 424, 2019. PMID: 31370298. DOI: 10.3390/medicina55080424

56 Wang $\mathrm{P}, \mathrm{Ng}$ QX, Zhang $\mathrm{H}$, Zhang $\mathrm{B}$, Ong $\mathrm{CN}$ and $\mathrm{He} \mathrm{Y}$ : Metabolite changes behind faster growth and less reproduction of Daphnia similis exposed to low-dose silver nanoparticles. Ecotoxicol Environ Saf 163: 266-273, 2018. PMID: 30056340. DOI: $10.1016 /$ j.ecoenv.2018.07.080
Received May 5, 2021

Revised May 31, 2021

Accepted June 3, 2021 